\title{
Fuel Cell Technology for Propulsion and Power Generation of Ships: Feasibility Study on Ocean Research Vessel Sagarnidhi
}

\author{
Rajasekhar D., Deepak Sankar P. S., Ananthakrishna, and Narendrakumar D. \\ Vessel Management Cell, National Institute of Ocean Technology, Chennai, India
}

\begin{abstract}
Rising fuel prices, increasing emission levels and impending environmental regulations made shipping industry to find an alternate for internal combustion engine in 21 st century. Fuel cell is a sustainable, emerging technology with negligible pollution. More significantly for a research ship, emission levels need to be substantially low to have quality measurements. A feasibility study is carried-out First time in the world, to drive an ice class multi-disciplinary ORV (Oceanography Research Vessel) Sagarnidhi, using hydrogen powered fuel cell. Sagarnidhi is equipped with special equipments viz., Deep Sea winch, specially designed cranes for Launching and retrieval of ROV (Remotely Operable Vehicle), DSMC (Deep Sea Mining Crawler), Tsunami systems, manned/unmanned submersible and ACS (Autonomous Coring System) and other facilities that support research in Indian, International and Antarctic waters. Beside this, the propulsion system along with DP (Dynamic Positioning), centralized air conditioning and special equipments require enormous electrical power. The combustion of diesel oil in an engine, that coupled with an alternator generates electrical power required, along with NOx (Nitrous Oxides), SOx (Sulphur Oxides) and PM (Particulate Matter) emissions. Shipping industry is the fourth largest contributor to air pollution and carbon emissions, particularly in coastal areas, and the growth rate makes the problem even more critical. Stringent international air pollution regulation and increasing fuel price paves the way for an alternative "green emission technology". Various fuel cells were analyzed with different combination of fuel, electrolyte and electrodes. From the analysis, it has been found that SOFC (Solid Oxide Fuel Cell) is most suitable for the present scenario. A fuel cell designed with hydrogen as fuel, zirconium oxides stabilized with yttrium oxide as electrolyte and zirconium electrodes is used for 1.5 MW power output and $0.5 \mathrm{MW}$ through regenerator. Volume required for storage of hydrogen is in line with volume of fuel and a high standard safety measures were taken using sensors. The present system saves $3000 \mathrm{MT} / \mathrm{annum}$ of diesel oil costing 3,000,000 USD approximately.
\end{abstract}

Key words: Hydrogen, air pollution, SOx, fuel cell, regenerator, particulate matter.

\section{Introduction}

1.1 International Convention for the Prevention of Pollution from Ships (MARPOL)

IMO (International Maritime Organization) has urged its member countries on marine pollution from ships. Annually, ocean going ships consumes 300 MMT (million metric tons) of fuel, estimated to emit 1.2-1.6 MMT of particulate matter, 12-14 MMT SOx emissions and 22-24 MMT NOx emissions. Nearly

Corresponding Author: Rajasekhar D., B.E (Mech), M.S., M.I.E (Marine), F.I.E (Marine), research fields: green technology, clad welding, sea-keeping capability of ships. Email: rajasekhar@niot.res.in.
$70 \%$ of ship emissions occur within $400 \mathrm{~km}$ of land, leading to significant pollution contribution to coastal communities. Marine pollution act 73/78 Annexure VI sets limits on ozone depleting substances viz., global Sulphur emission to $3.5 \%$, then progressively to $0.5 \%$, effective from 1st January 2020. The limits applicable in ECA (Emission Control Area) for $\mathrm{SO}_{\mathrm{x}}$ and particulate matter were reduced to $0.1 \%$, effective from 1st January 2015.

DNV GL (Det Norske Veritas-Germanischer Lloyd) regulations are for classification, verification, risk-management, and technical advisory to the maritime industry on safety, enhanced performance, fuel efficiency, etc. As a classification society, DNV 
GL sets standards for ships and offshore structures-known as Class Rules. They comprise safety, reliability and environmental requirements that vessels and other offshore mobile structures in international waters must comply with. DNV GL is authorized by 130 maritime administrations to perform certification or verification on their behalf.

\subsection{Objectives}

In a research vessel, launching and recovery of scientific equipment such as DSMC, ROV, ACS and so on needs a highly reliable DP system to carry out the operations for several hours in a particular station.

Ship propulsion and DP system consume enormous electrical power. The proposed plant is designed to deliver green energy. The main objectives of this work includes

- To develop and implement environmental friendly, cost saving innovative technology as an alternative to conventional energy.

- To minimize air pollution and Particulate Matter level by reducing carbon, SOx and NOx emission.

- Develop engineering solution to minimize global warming.

- Motivate shipping industry for the use of emerging technology.

\section{Solid Oxide Fuel Cell (SOFC)}

A fuel cell generates electricity through electrolysis process with low to zero emissions and the four basic components of the system are, Fuel cell stack which generates direct current, Fuel processor to converts fuel into a useable form, Current inverters and conditioners and Heat recovery system. Fig. 1 shows the schematic representation of a fuel cell.

$\mathrm{H}_{2}$, CO, methanol, diesel, gasoline and methane and so on are the primary fuels that are directly used in fuel cell stack [1]. Table 1 shows various materials used for SOFC components. Merits of SOFC includes

- Efficient allows variety of hydrocarbon fuels and suitable for indoor installation $[2,3]$.
- Potential long life expectancy [4] of 80000 hours.

- Flexible design, no external reformer is needed.

- Eliminates the exhaust of dangerous CO.

A research vessel is designed and equipped with scientific equipments to carry out any type of research at sea. Research ship with icebreaker hull suits for navigation in polar waters. Research ships usually have number of scientific equipments viz., CTD (Conductivity Temperature Depth), ADCP (Acoustic Doppler Current Profiler), Singlebeam and Multibeam Echosounder, Radiometer and so on. Some of the equipments are portable, rest of them are either hull mounted or special provisions like gondola through which under water sensors are fixed. Specially designed cranes, deep sea winch, A-frame etc., are few handling system used for carrying out research. Navigational control and dynamic positioning are the need of some of the research activities.

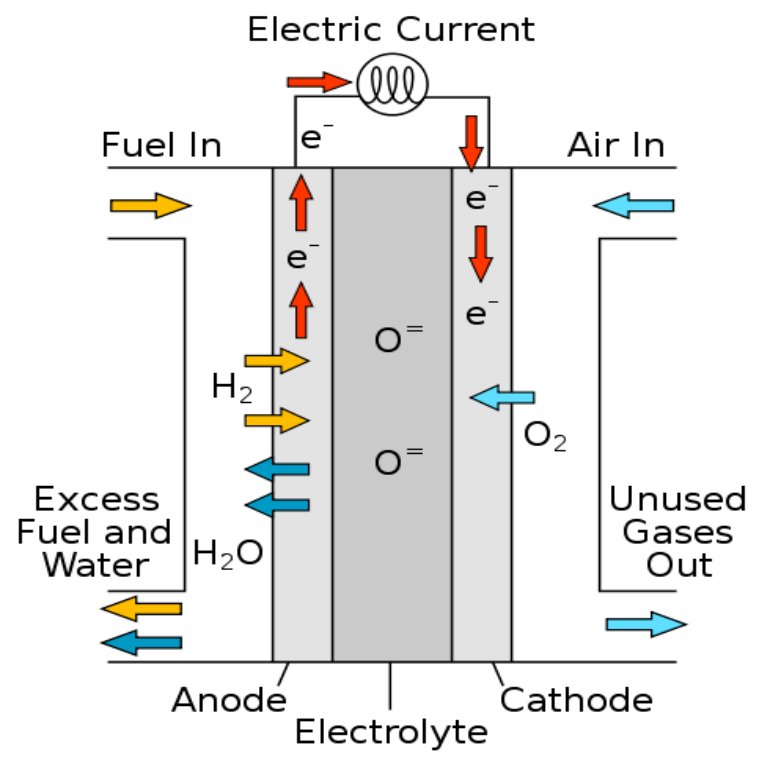

Fig. 1 Scheme of fuel cell.

Table 1 SOFC component materials.

\begin{tabular}{ll}
\hline Component & Preferred Materials \\
\hline Electrolyte & $\mathrm{ZrO}_{2}-\mathrm{Y}_{2} \mathrm{O}_{3}(3-10$ mol. \%) \\
Cathode & $\mathrm{La}_{1-\mathrm{x}} \mathrm{Sr}_{\mathrm{x}} \mathrm{MnO}_{3}$ \\
Anode & $\mathrm{Ni} / \mathrm{ZrO}_{2}-\mathrm{Y}_{2} \mathrm{O}_{3}$ \\
Interconnect & $\mathrm{La}_{1-\mathrm{x}} \mathrm{Sr}(\mathrm{Ca}, \mathrm{Mg})_{\mathrm{x}} \mathrm{CrO}_{3}$ \\
Manifold & Ceramics, metals \\
\hline
\end{tabular}


Feasibility Study on Ocean Research Vessel Sagarnidhi

For this study a research vessel ORV Sagarnidhi, is chosen is shown in Fig. 2. This is an ice class multi disciplinary research vessel having a versatile ocean observing platform equipped with technologically advanced scientific equipments and related facilities utilized for deployment and retrieval of Remotely Operated Vessel, Deep Sea Mining Crawler, Autonomous Coring System, Autonomous Underwater Vehicle, Tsunami systems so on. This vessel has fully automatic diesel-electric propulsion equipped with class-2 DP System and with a winch to hoist $60 \mathrm{~T}$ from a depth of 6,000 meters. The vessel is designed with blue-water capability with range of up to 10,000 nautical miles to carry out Geo-scientific, Meteorological and Oceanographic research in Indian and International waters including research at Antarctica waters. The ship details are shown in Table 2. Fig. 3 shows launching of Deep sea mining crawler onboard the vessel.

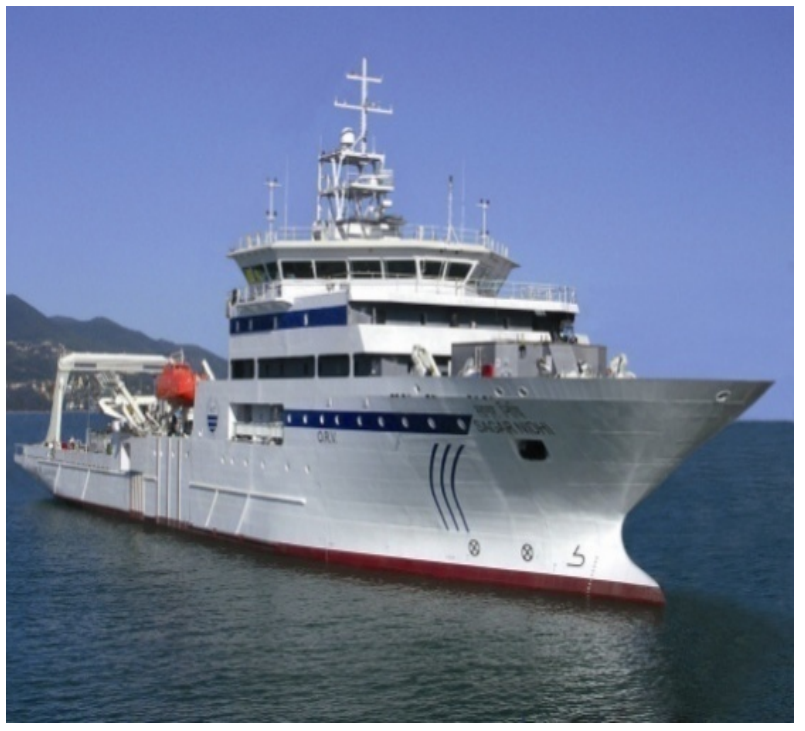

Fig. 2 ORV Sagar Nidhi.

Table 2 General characteristics of Sagar Nidhi.

\begin{tabular}{ll}
\hline Hull form & Mono hull \\
\hline Class notations & ICE class 1C and DP II \\
Length & $103.6 \mathrm{~m}$ \\
Beam & $18 \mathrm{~m}$ \\
Draft & $4.20 \mathrm{~m}$ \\
Service speed & $15 \mathrm{knots}$ \\
GRT & $4862 \mathrm{~T}$ \\
\hline
\end{tabular}

ORV Sagarnidhi is equipped with four main diesel generators, each of capacity $1400 \mathrm{~kW}$ and an emergency generator of $532 \mathrm{~kW}$ together delivers a total power of $6132 \mathrm{~kW}$. The power requirement for various onboard operations is shown in Table 3. Since all machineries are not operated at a time, power generated is well sufficient. Fig. 4 shows arrangement of diesel generators.

\section{Sagar Nidhi-SOFC Design and Implementation}

\subsection{Centralized Hybrid SOFC with Gas Turbine}

A new concept is proposed here to design a fuel cell

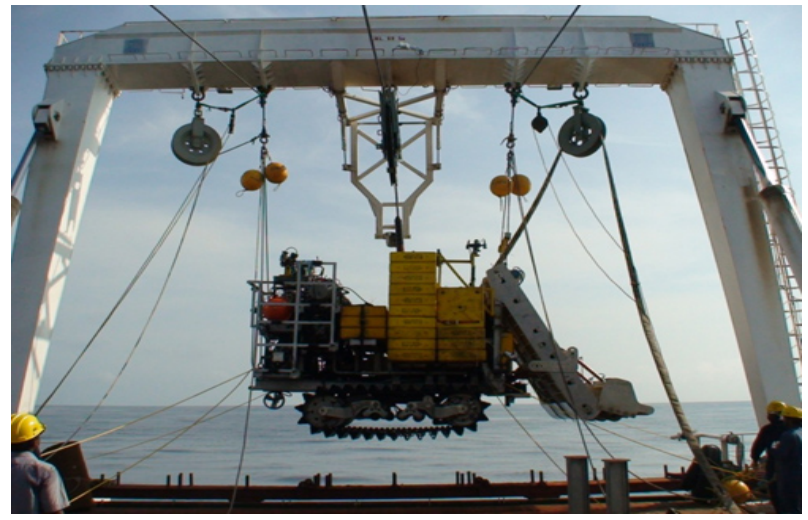

Fig. 3 Deep sea mining crawler.

Table 3 Ship load requirement.

\begin{tabular}{ll}
\hline Load application & Power (kW) \\
\hline Propulsion: Azimuth Thrusters & 3200 \\
Bow Thruster & 1600 \\
Machineries/Scientific Equipments & 3250 \\
Lighting and Miscellaneous & 165 \\
\hline
\end{tabular}

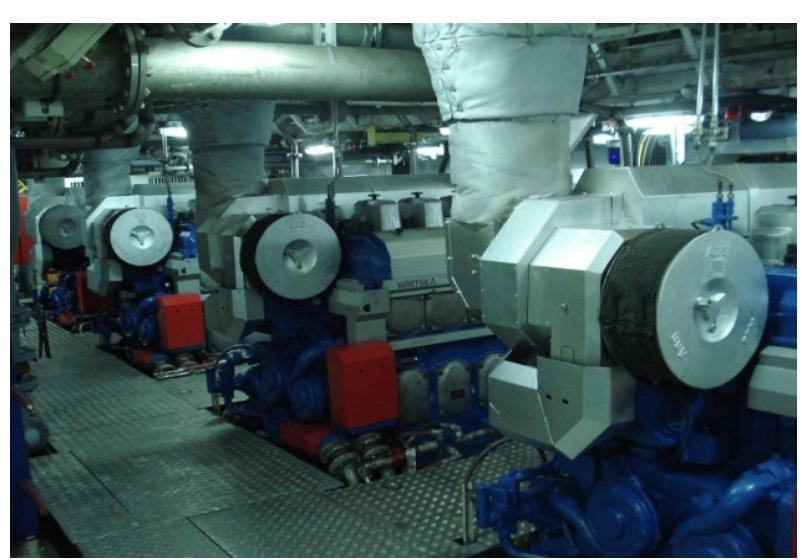

Fig. 4 Diesel generator for power generation. 


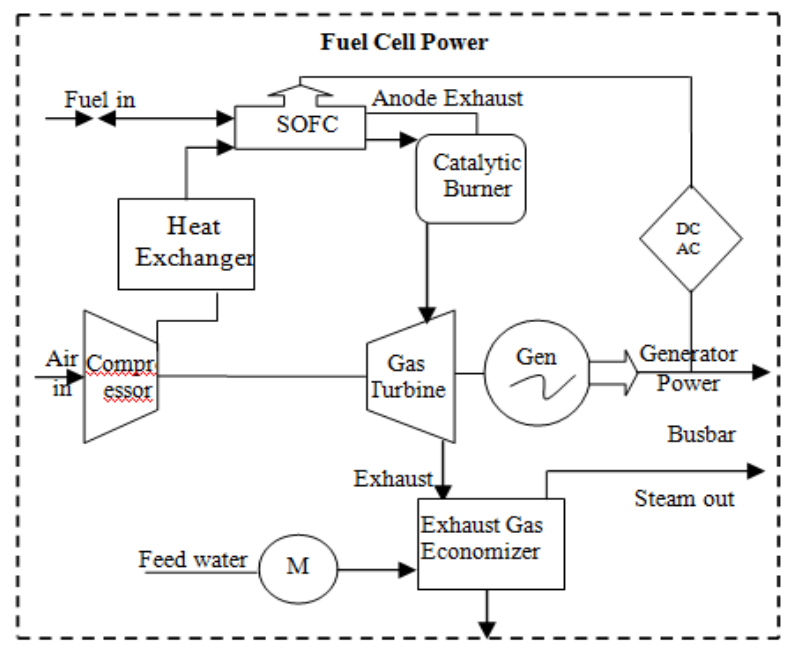

Fig. 5 Proposed scheme of SOFC plant with Gas Turbine.

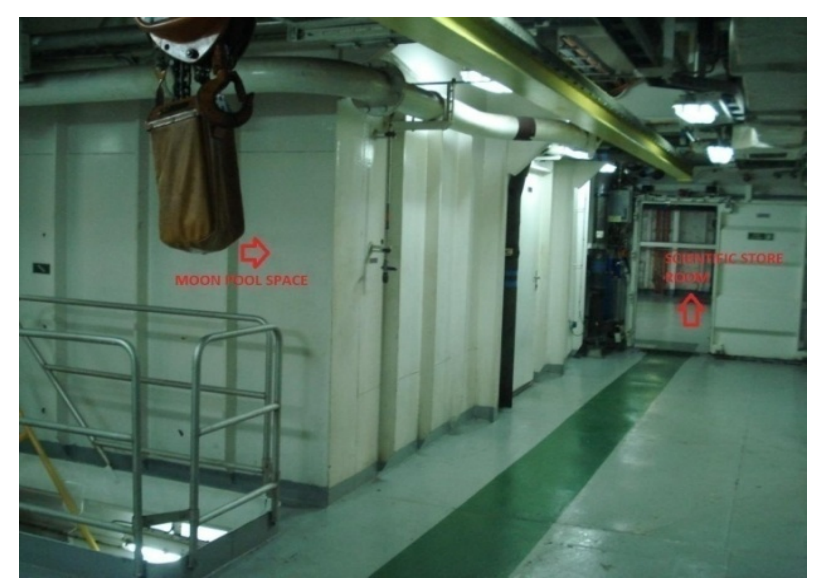

Fig. 6 Space for SOFC plant.

driven propulsion system. Huge power requirement, large space for hydrogen storage, safety aspects [5], high pressure storage, and present ship board arrangement and so on are the few constraints to be addressed during implementation.

The schematic representation of SOFC plant [6] is shown in Fig. 5. A hybrid SOFC with Gas turbine [7] with fuel cell output of $1500 \mathrm{~kW}$ and $500 \mathrm{~kW}$ from Gas turbine coupled generator is proposed for producing green energy. A catalytic burner connected to the exhaust of anode to convert any fuel left into heat energy will increase the exhaust temperature. Turbine will drive the compressor to deliver air to SOFC modules, saves auxiliary power and increases total system efficiency. The turbine also drives a generator, generate additional electrical power. Since the vessel does not have steam production units, it is a difficult task to run the engine when the vessel proceeds to colder climates for scientific expeditions. Steam can be produced using the exhaust from turbine, fed into an EGE (Exhaust Gas Economizer) which in turn used for fuel oil heating, hot water production, steam tracers for various storage tanks and for purifiers so on. A fuel utilization of $90 \%$, air utilization of $25 \%$ and Air/fuel inlet temperature of $600-700{ }^{\circ} \mathrm{C}$ is taken for the proposed plant as these values are apt and yield the highest efficiency.

\subsection{SOFC Cell and Stack Design}

It is known that cell current depends on the area of a cell. Fuel cells are arranged in the form of stack to get the required power output. The following calculations show area of each fuel cell number of cell stacks required for the proposed SOFC power plant of desired output of 1.5 MW DC with desired operating point of $900 \mathrm{mV}$ and $900 \mathrm{~mA} / \mathrm{cm}^{2}$.

\section{Desired Power output $=$}

Voltage $\mathrm{x}$ Current Density $\mathrm{x}$ Total cell area

$1.5 \times 10^{6}=900 \times 10^{-3} \times 900 \times 10^{-3} \times 10^{4} \times$ Total cell area

\section{Total cell area $=185.19 \mathrm{~m}^{2}$}

Assuming $40 \mathrm{~cm}$ x $30 \mathrm{~cm}$ cell used;

No of cells required is $=185.19 /(0.4 \times 0.3)=$ 1543.21 1544 Cells.

Assuming 120 cells per stack;

No of stacks required is $=1543 / 120=12.86 \sim \mathbf{1 3}$ stacks.

Fig. 6 shows the scientific store and moon pool, which was considered for installation of SOFC plant. It is planned to have stack in lower scientific store room which is having the dimension of $7.2 \times 5.5 \times 3.1$ $\mathrm{m}$. For hydrogen plant, upper scientific store room is considered which is having the dimension of $9.8 \mathrm{x}$ $10.7 \times 2.5 \mathrm{~m}$.

The space available in moon pool is $=7.2 \times 4.5 \mathrm{x}$ $6.55 \mathrm{~m}$. Since each cell is having the thickness of 0.02 $\mathrm{m}$, volume of each stack $=0.4 \times 0.3 \times(0.02 \times 120)=$ 
$0.4 \times 0.3 \times 2.4 \mathrm{~m}$. Total space requirement for 13 stacks can be represented as shown in following two options.

Option 1: $5.2(\mathrm{~L}) \times 0.3(\mathrm{~B}) \times 2.4 \mathrm{~m}(\mathrm{H})$

Option 2: $2.6(\mathrm{~L})$ x $0.6(\mathrm{~B}) \times 2.4 \mathrm{~m}(\mathrm{H})$

An additional area of approximately $6 \times 6 \times 3 \mathrm{~m}$ is required for the turbine driven compressor, generator, co-generation unit and power conditioning and monitoring console.

\subsection{Flow Rate of the Reactants}

The air flow rate, fuel flow rate and hydrogen consumption for the proposed $2 \mathrm{MW}$ (1.5 MW plant power and 0.5 MW regenerator power) plant was calculated as below. Fuel utilization of $90 \%$, air utilization of $25 \%$, cell voltage of $900 \mathrm{mV}$ is considered for the proposed plant.

$$
\text { We know, } I=\frac{P}{V}=\frac{1.5 \times 10^{6}}{0.9}=1666.67 \mathrm{kA}
$$

For every molecule of hydrogen $\left(\mathrm{H}_{2}\right)$ that reacts within a fuel cell, two electrons are liberated at the fuel cell anode.

$$
\mathrm{H}_{2} \rightarrow 2 \mathrm{H}^{+}+2 \mathrm{e}^{-}
$$

The quantity of hydrogen consumed within the fuel cell stack for producing one ampere current is calculated as below:

$$
\begin{gathered}
\mathrm{nH}_{2}=1 \mathrm{~A} \cdot \frac{1 \text { coulomb/sec }}{1 \mathrm{~A}} \cdot \frac{1 \text { equivalance of } \mathrm{e}^{-}}{96,487 \text { coulombs }} \cdot \frac{1 \mathrm{~g} \mathrm{~mol} \mathrm{H}_{2}}{2 \text { equivalance of } \mathrm{e}^{-}} \cdot \frac{3600 \mathrm{sec}}{1 \mathrm{hr}}=0.018655 \frac{\mathrm{g} \mathrm{mol}}{\mathrm{hr}-\mathrm{A}} \mathrm{H}_{2} \\
\mathrm{mH}_{2}=0.018655 \frac{\mathrm{g} \mathrm{mol}}{\mathrm{hr}-\mathrm{A}} \mathrm{H}_{2} \cdot \frac{2.0158 \mathrm{~g}}{1 \mathrm{~g} \mathrm{~mol} \mathrm{H}} \cdot \frac{1 \mathrm{~kg}}{1000 \mathrm{~g}}=37.605 \times 10^{-6} \frac{\mathrm{kg} \mathrm{H}_{2}}{\mathrm{hr}-\mathrm{A}}
\end{gathered}
$$

One equivalence of electrons is $1 \mathrm{~g}$ mol of electrons [8] or $6.022 \times 10^{23}$ electrons (Avogadro's number). This quantity of electrons has the charge of 96,487 coulombs (C). Thus, the charge of a single electron is $1.602 \times 10^{-19} \mathrm{C}$.

For $1666.67 \mathrm{kA}$, the Hydrogen requirement is $1666.67 \times 37.605 \times 10^{-6}=61.54 \sim 62 \mathrm{~kg} / \mathrm{hr}$. Since the fuel utilization of $90 \%$ is considered, the actual hydrogen [9] requirement is $61.54 / 0.9=68.38 \mathrm{~kg} / \mathrm{hr}=$ $1641 \mathrm{~kg} /$ day.

\subsection{Air Flow Rate}

By considering the stoichiometric ratio of hydrogen to oxygen is $2: 1$ for $\mathrm{H}_{2} \mathrm{O}$,

$\begin{array}{llll}\mathrm{O}_{2} & \text { consumed } & = & 61.54\end{array}$ $\mathrm{H}_{2} \cdot \frac{1 \mathrm{~kg} \mathrm{~mol} \mathrm{H}}{2.0158 \mathrm{~kg} \mathrm{H}_{2}} \cdot \frac{1 \mathrm{~kg} \mathrm{~mol} \mathrm{O}}{2 \mathrm{~kg} \mathrm{~mol} \mathrm{H}}=15.26 \mathrm{~kg} \mathrm{~mol} \mathrm{O} / \mathrm{hr}=$ $488.28 \mathrm{~kg} \mathrm{O}_{2} / \mathrm{hr}$

Considering $25 \%$ of utilization, $\mathrm{O}_{2}$ consumed $=$ $1953.11 \mathrm{~kg} \mathrm{O}_{2} / \mathrm{hr}$

$$
\begin{array}{llll}
\text { Air } & \text { supplied } & 1953.11 \quad \mathrm{~kg}
\end{array}
$$

$\mathrm{O}_{2} \cdot \frac{1 \mathrm{~kg} \mathrm{molO}}{31.988 \mathrm{~kg} \mathrm{O}_{2}} \cdot \frac{1 \mathrm{~kg} \mathrm{~mol} \mathrm{air}}{0.21 \mathrm{~kg} \mathrm{~mol} \mathrm{O}}=290.75 \mathrm{~kg} \mathrm{~mol} \mathrm{air} \mathrm{/}$ $\mathrm{hr}=8387.7 \mathrm{~kg} \mathrm{air} / \mathrm{hr}$

\subsection{Hydrogen Compression/Storage}

Hydrogen is the lightest gas, in the entire universe, weighs only $90 \mathrm{mg} /$ liter under normal atmospheric pressure, which necessitates the need of large storage space, which can be reduced by increasing the density of hydrogen. Table 4 shows amount of hydrogen and air requirement for the proposed plant. For a cruise of 30 days, the total amount of hydrogen requirement at optimum speed is calculated as 49.23 Ton. Space required to store the required hydrogen is calculated as below by rearranging the ideal gas law equation we can find density of a gas by the following:

Ideal gas equation: $\mathrm{PV}=\mathrm{nRT}$;

$$
\mathrm{PV}(\mathrm{MW})=\mathrm{n}(\mathrm{MW}) \mathrm{RT}=\operatorname{mass} \mathrm{x} \mathrm{RT}
$$

At one atmospheric pressure and at a temperature of $298 \mathrm{~K}$, the molecular weight of hydrogen (MW) is 2 $\mathrm{g} / \mathrm{mol}$. Density of hydrogen

$$
(\rho)=\frac{P(M W)}{R T}=\frac{10^{5} \times 2 \times 10^{-3}}{8.314 \times 298}=0.081 \mathrm{~kg} / \mathrm{m}^{3}
$$

Volume required to store $49232 \mathrm{~kg}$ of hydrogen is $607803 \mathrm{~m}^{3}$. Since the volume occupied by hydrogen is 
Table 4 Hydrogen, Oxygen and Air requirement for various conditions.

\begin{tabular}{lllll}
\hline Conditions & Power requirements & Hydrogen requirement & Oxygen requirement & Air supplied \\
\hline Steaming & $1.5 \mathrm{MW}$ & $1.641 \mathrm{Ton} /$ day & $46.875 \mathrm{Ton} / \mathrm{day}$ & 201.31 Ton/day \\
Anchorage/DP & $0.8 \mathrm{MW}$ & $0.875 \mathrm{Ton} /$ day & $25 \mathrm{Ton} /$ day & 107.36 Ton/day \\
Shore/Berth & $0.8 \mathrm{MW}$ & $0.875 \mathrm{Ton} /$ day & $25 \mathrm{Ton} /$ day & 107.36 Ton/day \\
\hline
\end{tabular}

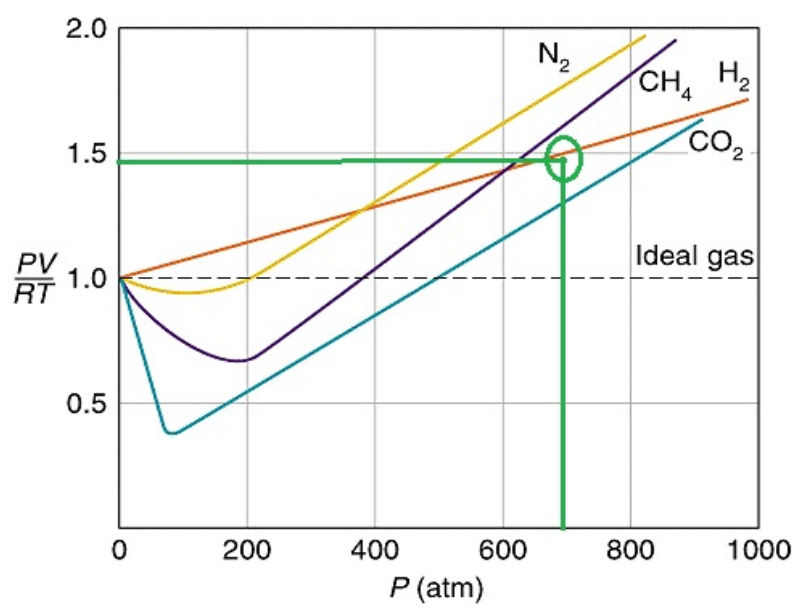

Fig. 7 Compressibility factor chart.

huge, hydrogen storage in a compressed form is advisable. Considering the storage of hydrogen [10] at 700 bar and at $298 \mathrm{~K}$, Volume required to store $1 \mathrm{~kg}$ of hydrogen,

$$
\mathrm{V}=\frac{\mathrm{ZRT}}{\mathrm{P}(\mathrm{MW})}=\frac{1.46 \times 8.314 \times 10^{3} \times 298}{700 \times 10^{5} \times 2}=0.0258 \mathrm{~m}^{3}
$$

where $\mathrm{Z}$ is compressibility factor [11] and from the Fig.7, the value found to be 1.46. Compressing the hydrogen saves huge volume required to store. The volume required to store is found to be $1272 \mathrm{~m}^{3}$.

\subsection{Tank Design and Size:}

Low hydrogen density of high pressure vessels is the primary concern in compressed hydrogen storage techniques $[12,13]$. It is proposed to have two cylindrical tanks each of $636 \mathrm{~m}^{3}$ to store hydrogen.

The volume of each tank is: $\mathrm{V}=\pi \mathrm{R}^{2} \mathrm{~L}=636 \mathrm{~m}^{3}$

By substituting the value for $\mathrm{R}$ and $\mathrm{L}$, different option of tank sizes can be obtained.

For example if we choose the length $\mathrm{L}$ as $6 \mathrm{~m}$ then; $603=3.14 \times R_{2} \times 6$

$\mathrm{R}_{2}=1206 / 3.14 \times 6=603 / 25.12=32$; Radius of each tank $(\mathrm{R})=5.5 \mathrm{~m}$ and length of each tank is $(\mathrm{L})=$ $6 \mathrm{~m}$
Hydrogen is typically compressed by a reciprocal compressor. High strength, carbon fiber composite pressure vessels rated to 700 bar will achieve a better gravimetric and volumetric storage density. Compressed hydrogen is used in many prototype fuel cell vehicles, since storage of hydrogen is relatively simple and filling tank can be completed in a short time.

The main disadvantages are its low volumetric and gravimetric densities compared to other storage methods. Another shortcoming of compressed hydrogen is the public's perception of safety concerns associated with extremely high pressure hydrogen tanks. However, recent test results have indicated that 700 bar composite vessels may actually be safer than their low pressure counterparts widely used in industry, primarily because of thicker tank walls [14].

\subsection{Energy Required for Compressing Hydrogen:}

Theoretical calculations assume hydrogen generated at 20 bar and at $300{ }^{\circ} \mathrm{K}$ before it is compressed. If hydrogen were only available at ambient conditions (1 atm, $300{ }^{\circ} \mathrm{K}$ ), an additional energy of $1.02 \mathrm{kWh} / \mathrm{kg}$ is required.

Energy required for compressing the hydrogen,

$$
\mathrm{W}=\mathrm{RT}_{1} \ln \frac{\mathrm{P}_{2}}{\mathrm{P}_{1}}=4.157 \times 300 \ln \frac{700}{1}=8170 \mathrm{~kJ} / \mathrm{kg}=2.27 \mathrm{kWh} / \mathrm{kg}
$$

\section{Economy and Safety Considerations}

\subsection{Cost Comparison and Cost Saving Analysis}

Cost of Hydrogen [15] is dependent on several factors such as demand and supply and also transportation cost. The Equivalent energy is making the base price of Hydrogen. The HHV (Higher Heating Value) of Hydrogen is $141 \mathrm{MJ} / \mathrm{Kg}$, and that of Methane is $55 \mathrm{MJ} / \mathrm{Kg}$. Natural gas is available at Rs. 
$30 / \mathrm{Kg}$. Thus Hydrogen price cannot be lower than 30 x $141 / 55=$ Rs. 76 per kg.

Cost for a period of 30 day cruise $=49230 \times 76=$

\section{Rs 37,41,480}

In India, the average price of LSHFHSD per ton is Rs 55,000 . The $\mathrm{HHV}$ is about $48 \mathrm{MJ} / \mathrm{Kg}$.

Total amount of LSHFHSD required for a 30 day cruise $=30 \times 8=240$ tons

Price of 240 ton of LSHFHSD $=240 \times 55000=$

\section{Rs.1,32,00,000}

Total price that can be saved in a 30 day cruise $=$ $1,32,00,000-37,41,480=$ Rs. $94,58,520$

LNG (methane) as fuel:

In case of using methane as fuel by direct reforming at the SOFC stack then cost analysis can be done as follows:

Price of LNG in India = Rs 450/MMBTU; density = $0.66 \mathrm{~m}^{3}$; Therefore price of $\mathrm{LNG} / \mathrm{kg}=$ approx Rs 30

Methane flow rate required for producing hydrogen at $\mathrm{SOFC}=4 \mathrm{~mol} / \mathrm{sec}$

$1 \mathrm{~mol}$ of methane $=16 \mathrm{~g} ; 4 \mathrm{~mol} / \mathrm{sec}=64 \mathrm{~g} / \mathrm{sec}=$ $230.4 \mathrm{~kg} / \mathrm{hr}$

Total amount of LNG required to carry out a 30 day cruise $=230.4 \times 24 \times 30=\mathbf{1 , 6 5 , 6 0 0 ~} \mathbf{~ k g}$

Cost of $165888 \mathrm{~kg}$ of $\mathrm{LNG}=165888$ × $30=$ Rs.

\section{$49,76,640 /-$}

\subsection{On Site Hydrogen Generators}

In order to replenish the hydrogen during cruise period and also to cut down the cost of fuel further, it is proposed to have a hydrogen production [16] plant operating with electrolysis principle. In this method an electric current is passed through the water to split it into hydrogen and oxygen. Electrolysis is less efficient than a direct chemical path but offers virtually no pollution or toxic byproducts. Since the power is generated through the generator by utilizing the waste heat from the SOFC stack the efficiency can be improved. Fig. 8 shows proposed hydrogen generation plant.

We propose a high pressure Bipolar Alkaline type water electrolysis Hydrogen plants which directly produce Hydrogen at high pressure of about 15-30 bar. Considering the space and weight constraints we propose three production plants with capacity of 60 $\mathrm{m}^{3} / \mathrm{hr}$ (total $180 \mathrm{~m}^{3} / \mathrm{hr}$ ) with $99.999 \%$ purity. The dimensions of each plant are $6.4 \mathrm{M}$ x $2.44 \mathrm{M} \times 2.8 \mathrm{M}$.

Total hydrogen produced [17] in a 30 days cruise is $30 \times 24 \times 180=129600 \mathrm{~m}^{3}=11665 \mathrm{~kg}$

Therefore the cost of fuel further saved during a 30 day cruise $=11665 \times 76=$ Rs 8,86,540

Based on the flow rate calculation the amount of fuel required per day and for a 30 day cruise was calculated. The above chart comparison shows the cost of hydrogen, LNG and diesel oil for a 30 day cruise,

Cost of hydrogen $=37.4$ Lakhs; Cost of LNG $=$ 49.8 Lakhs; Cost of LSHFHSD = 132 Lakhs

When hydrogen is opted as fuel, a cost saving of Rs. 3.15 lakhs/day can be achieved and Rs 94.6 lakhs can be achieved for a total period of 30 days.

\subsection{Safety Aspect Comparison between Hydrogen, Methane and Gasoline}

Table 5 shows Hydrogen is as dangerous as the gasoline and LNG. A rapid dispersion rate is probably hydrogen's greatest safety asset in an outdoor environment, although wind and the escape velocity from a high-pressure tank may have more influence on the size of a flammable hydrogen cloud. The wide

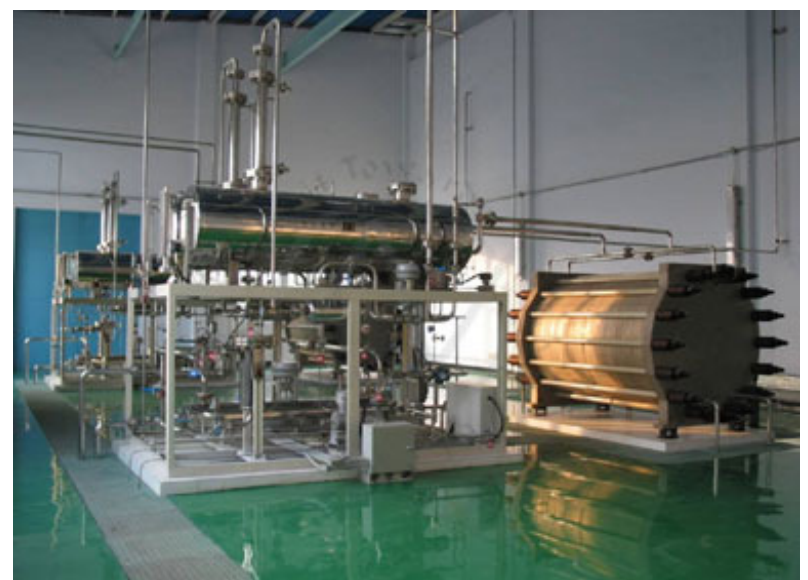

Fig. 8 Hydrogen generation plant. 
Table 5 Comparison between $\mathrm{H}_{2}$, LNG and methane based on property.

\begin{tabular}{llll}
\hline Property or event & Hydrogen & Methane & Gasoline \\
\hline Size of molecules & Smallest, $(+)$ & Small $(++)$ & Big $(+++)$ \\
Leakage rate & Highest $(+)$ & high $(++)$ & low $(+++)$ \\
Fire hazard from spills & Fast $(+)$ & Intermediate $(++)$ & Low $(+++)$ \\
Fire duration & Shortest $(+++)$ & Intermediate $(++)$ & Longest $(+)$ \\
Odorization for leak detection & Not allowed in fuel cells $(+)$ & Artificially odorized $(++)$ & Normally odorous $(+++)$ \\
Buoyancy (at NTP) & 14.5 times lighter than air $(+++)$ & 1.8 times lighter than air $(++)$ & Heavier than air $(+)$ \\
Energy of explosion & Lowest $(+++)$ & Intermediate $(++)$ & Highest $(+)$ \\
Flammability limits & Broadest limits $(+)$ & Intermediate limits $(++)$ & Narrowest limits $(+++)$ \\
\hline
\end{tabular}

$(+++)$ more plus more safe.

Table 6 Emission and fuel cost for a 30 days cruise.

\begin{tabular}{llllll}
\hline & NOx & SOx & CO $_{2}$ & Particulate & Cost \\
\hline LSHFHSD & 10.8 & 4.3 & 580 & 0.2 & $13,200,000$ \\
LNG & 1.5 & 0.3 & 400 & 0.03 & $4,976,640$ \\
$\mathbf{H}_{2}$ & 0.2 & 0.1 & 2 & 0.006 & $3,741,480$ \\
\hline
\end{tabular}

flammability range of hydrogen-air mixtures compared to the other fuels is a disadvantage.

The low flame emissivity of hydrogen reduces the heat transferred by radiation to objects near the flame and reduces the risks of secondary ignitions and burns. Most accidental hydrocarbon flames, such as those from propane, natural gas, and gasoline, also contain soot that increases the amount of heat radiated. A hydrogen flame is invisible in daylight and emits a low level of thermal radiation. Even if location is known, the envelope of the flame is not always easily distinguishable. Although hydrogen and its combustion product, water vapor are not considered to be toxic leakage and fires of hydrogen cause suffocation by decreasing ambient oxygen concentration. Furthermore, the main danger in handling of hydrogen lies in its high flammability in air or oxygen. Its combustible character may result in a fire, a relatively weak explosion or a severe explosion. DNV GL regulations for safety aspects were considered.

\section{Results and Discussion}

Table 6 shows emission rate and cost for various fuels. It is clear that the marine diesel oil emissions are high when compared with LNG and hydrogen.
LNG has high $\mathrm{CO}_{2}, \mathrm{NO}_{\mathrm{x}}$, and $\mathrm{SO}_{\mathrm{x}}$ emission compared with hydrogen. Hence hydrogen is found to be the better alternative green fuel for the future.

Implementing the fuel cell onboard will have large no of advantages to the ship in carrying out scientific operations. The lack of moving parts means that noise emissions are expected to be extremely low in comparison to rotating machinery. It has major benefits for surveying with sonar, or other acoustic based operations. This "green emission" technology has become increasingly popular with facilities looking to implement an environmentally-friendly electric power generation system without sacrificing efficiency, availability and performance.

\subsection{Efficiency Comparison between Fuel Cell and Internal Combustion Engine}

Average Hydrogen consumption/day $=1641 \mathrm{Kg}=$ $1641 /(24 \times 60 \times 60)=0.01899 \mathrm{Kg} / \mathrm{s}$

Energy Input $=0.01899 \times 142=2.697 \mathrm{MW}$

Electrical Output from Fuel Cell $=1.5 \mathrm{MW}$

Efficiency of System $=1.5 / 2.697=55.62 \%$

Electrical output from regenerator $=0.5 \mathrm{MW}$

Total Electrical Output $=2 \mathrm{MW}$

Overall Efficiency $=2 / 2.697=74.16 \%$

Specific Energy of Low Sulphur High Flash High 


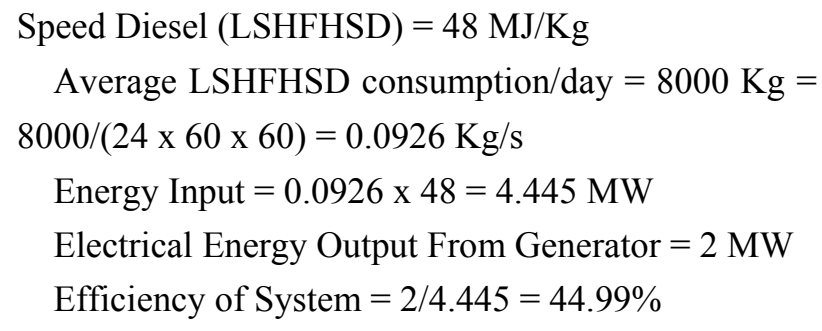

\section{Conclusion with Recommendation}

The shipping industry is under pressure to reduce $\mathrm{CO}_{2}, \mathrm{NO}_{\mathrm{x}}, \mathrm{SO}_{\mathrm{x}}$ and particulate emissions. Stringent Maritime rules and regulations that safeguard the interests of society in this respect. The following conclusions were made after detailed feasibility study.

- Implementation of SOFC in Sagar Nidhi results in huge saving of diesel oil (3000 MT costing $3,000,000$ USD)

- $98.15 \%$ reduction on NOx, $97.67 \%$ reduction on SOx, $99.66 \% \mathrm{CO}_{2}$ and $97 \%$ reduction on particulate matter when fuel cell with $\mathrm{H}_{2}$ fuel replaces IC engine with diesel fuel.

- Volume for storage of hydrogen is in-line with storage of HSD.

- Since $\mathrm{H}_{2}$ is required to be compressed at a pressure of 700 bar to reduce the volume, a different set of safety rules $[18,19,20,21]$ may have to be followed. Separate study with the help of classification society is proposed to be under taken.

Switching over to the "Fuel Cell-Green Technology" will definitely address both the issues in near future. Further studies on capital cost, operational cost analysis of fuel cell system, the power conversion and distribution methods used in fuel cells, $\mathrm{H}_{2}$ production plant and updated classification rules to be complied are recommended to enhance the feasibility of implementing the system onboard.

\section{Acknowledgement}

The authors would like to acknowledge the contribution and support given by Dr. R. Venkatesan and Mrs. D. Bernardin Marina, of NIOT (National Institute of Ocean Technology) for their valuable suggestion and recommendation that helps in enriching this paper.

\section{References}

[1] Cannon, J. S. 1994. "Hydrogen Vehicles Programs in the USA.” Int J Hydrogen Energy 19 (11): 905-9.

[2] Stambouli, A. B., and Traversa, E. 2002. "Solid Oxide Fuel Cells (SOFCS): a Review of an Environmentally Clean and Efficient Source of Energy." Renewable and Sustainable Energy Reviews 6: 433-55.

[3] Janardhanan, V. M., and Deutschmann, O. 2007. "Efficiency Analysis of Planar Solid Oxide Fuel Cell" at Direct Internal Reforming Conditions. ECS Transactions 7 (1) 1939-43.

[4] Mazumder, S. K., Acharya, K., Williams, R., Spakovsky, M. R, Nelson, D. J., Rancruel, D. F., Hartvigsen, J., and. Gemmen, R. S. 2004. "Solid-Oxide-Fuel-Cell Performance and Durability: Resolution of the Effects of Power-Conditioning Systems and Application Loads." IEEE Transactions on Power Electronics 19 (5): 1263-77.

[5] "Hazards of Liquid Hydrogen", Position paper Prepared by the Health and Safety Laboratory for the Health and Safety Executive 2010.

[6] DNV, Fuel Cells for Ships. Research and Innovation, Position Paper 13-2012.

[7] Dustin Mclarty and Jack Brouwer 2010. "Hybrid Fuel Cell Gas Turbine System Design and Optimization for SOFC." In Proceedings of the ASME 2010 8th International Fuel Cell Science, Engineering and Technology Conference, Brooklyn, New York, USA.

[8] Eric W. Lemmon, Marcia L, Jacob W. Leachman, 2008 "Revised Standardized Equation for Hydrogen Gas Densities for Fuel Consumption Applications." Journal of Research of the National Institute of Standards and Technology 113 (6): 341-50.

[9] Huber Society of Automotive Engineers (SAE), "Recommended Practice for Measuring the Fuel Consumption and Range of Fuel Cell Powered Electric Vehicles Using Compressed Gaseous Hydrogen, in preparation," 2005.

[10] Bragin, M., and Molkov, V. 2010. "The Effect of Storage Pressure on Transient Combustion of Hydrogen Released through a Pipe to the Atmosphere." 6th International Seminar on Fire and Explosion Hazards, Leeds, 10-16.

[11] Li Zhoua, Yaping Zhou, 2001. "Determination of Compressibility Factor and Fugacity Coefficient of Hydrogen in Studies of Adsorptive Storage." International Journal of Hydrogen Energy 26: 597-601.

[12] Fred Mitlitsky, Andrew H. Weisberg, and Blake Myers 2000. "Vehicular Hydrogen Storage Using Lightweight 
Tanks." In Proceedings of the 2000 U.S. DOE Hydrogen Program Review.

[13] Ewald, R. 1998. "Requirements for Advanced Mobile Storage Systems." Int J Hydrogen Energy 23 (9): 803-14.

[14] Sirosh, N. 2002. "Hydrogen Composite Tank Program." In Proceedings of the 2002 U.S. DOE Hydrogen Program Review.

[15] Paulina, C. 2004. "Hydrogen Fuel Cell Vehicle Fuel Economy Testing at the U.S." EPA National Vehicle And Fuel Emissions Laboratory, Society of Automotive Engineers, Powertrain \& Fluid Systems Conference and Exhibition, 01-2900.

[16] Sherif, S. A., Barbir, F., and Veziroglu, T. N. 2003. "Principles of Hydrogen Energy Production Storage and Utilisation." Journal of Scientific and Industrial Research (60): 46-63.
[17] M. Cohen, Gerry C. Snow, and P. E. 2008. "Hydrogen Delivery and Storage Options for Backup Power and Off-Grid Primary Power Fuel Cell Systems." IEEE Intelec 2008 Proceedings.

[18] Ana Gundić, Vlado Frančić, "Particularity of Safety Measures on Board Ships Operating in the Motorways of the Sea Service."

[19] IMO maritime security policy - Background paper, Sixteenth OSCE Economic and Environmental Forum Part 1: "Maritime and Inland Waterways Co-Operation in the OSCE Area: Increasing Security and Protecting the Environment" Vienna: 28-9.

[20] Nora Berg, Jenni Storgård, and Jouni Lappalainen 2013. "The Impact of Ship Crews on Maritime Safety."

[21] Catherine Hetherington, Rhona Flin, and Kathryn Mearns 2006. "Safety in Shipping: the Human Element." 